\title{
An empirical investigation of the goals of listed firms on the Johannesburg Stock Exchange
}

\author{
Johan K. Bosch
}

Department of Business Economics, University of Port Elizabeth

\author{
Alwyn P. du Plessis \\ Port Elizabeth Technikon
}

\begin{abstract}
In economics and finance it is often assumed that firms merely seek the maximization of shareholder wealth. In order to test this hypothesis an empirical investigation on the goal structure of firms listed on the Johannesburg Stock Exchange was performed with special reference to the relative importance of the concept of shareholder wealth maximization and social responsibility of the firm.

The responses indicated that the wealth maximization hypothesis tested in this survey appears to be applicable for the firms which participated, albeit not always in terms of all the possible parameters of the wealth maximization hypothesis.

S. Afr. J. Bus. Mgmt. 1982, 13: 76-88

In die ekonomie asook in die finansiěle teorie word dikwels aanvaar dat ondernemings slegs op die maksimering van aandeelhouerswelvaart gerig is. Om hierdie hipotese te toets is ' $n$ empiriese ondersoek van die doelstruktuur van genoteerde ondernemings op die Johannesburgse Effektebeurs uitgevoer. Spesiale aandag is gegee aan die relatiewe belangrikheid van die begrippe van maksimering van aandeelhouerswelvaart, asook aan die maatskaplike verantwoordelikheid van ondernemings.

Die resultate van hierdie ondersoek bevestig die hipotese van die maksimering van aandeelhouerswelvaart vir die deelnemende ondernemings, alhoewel nie altyd in terme van al die moontlike parameters van die vermoënsmaksimeringshipotese nie.

S.-Afr. Tydskr. Bedryfsl. 1982, 13: 76-88
\end{abstract}

Financial support for the empirical survey granted by the Human Sciences Research Council. Ideas aired and conclusions made are those of the authors and not of the Human Sciences Research Council.
Much has been said and written on how firms ought to act, on whether or not firms have a social responsibility, and which objectives the firms ought to pursue, but very little has been said and little information given on how firms actually do act in practice..$^{1.2}$

The question of how managers, particularly professional managers in control of private firms, manage their firms and which primary goals they pursue, is of fundamental importance to those who teach in the economic sciences and more specifically business economics, as well as to other parties who are interested in business as such.

In economics and finance, as well as in certain other disciplines, it is often assumed that firms merely seek the maximization of shareholders' wealth. In finance textbooks statements like the following are quite common:

'We adopt in this book the concept that the firm should maximize stockholder wealth. This, in turn, implies that the firm should maximize its current stock price, . . 3, p.12

'In this book, we assume that the objective of the firm is to maximize its value to its shareholders. Value is represented by the market price of the Company's common stock, . . '4, pp.7-8

'The Goal of the Firm is the maximization of the market value of its own common stock - the maximization, that is, of the value of the equity owned by its stockholders - subject to whatever constraints, legal or moral, exist in the firm's environment.'s, p.10

Thus, in business finance literature it seems that the assumption that shareholders' wealth is to be maximized reigns supreme. Most texts qualify these statements by asserting that firms might have other objectives; however, such qualifications have little impact on the rest of the contents of these books. If other goals are indeed present, this approach may be inadequate or simply wrong.

The purpose of the research project on which this article reports, was to determine the primary goal or goals of firms listed on the Johannesburg Stock Exchange (JSE) and to establish the relative importance of the concepts of shareholder wealth maximization ${ }^{6}$ and social responsibility ${ }^{7}$ of the firm. The major hypotheses thus tested in this study are the validity of the goals of wealth maximization and social responsibility. The results of this study are of importance to those who teach business economics and related subjects, as a clear definition of the capitalist

\footnotetext{
Dr. J.K. Bouct:

Department of Business Economics, University of Pon Elizabeth, P.O. Box 1600, Port Elizabeth 6000 , Republic of South Africa

Deputy-director (Humanities), Port Elizabeth Technikon,

-To whom correspondence should be addressed

Received August 1981; accepted February 1982
} 
imperative is vital for the very survival of the South African economic system.

\section{Scope and method of research}

In determining the goal structure of firms, the research was limited to all companies listed on the JSE. Two considerations were paramount in selecting only listed companies, namely the fact that daily market values (prices) of shares constitute an actual (and useful) parameter of shareholder wealth, and secondly, the separation between ownership and management is theoretically the greatest in these firms with the result that better opportunities exist for determining the social responsibility attitudes of the firm. In order to gather the relevant information, questionnaires were sent to chief executives of all firms listed on the JSE.

A complete survey was done and in total 505 questionnaires were posted to all firms listed on the JSE, addressed personally to either the managing director or the chairman of the specific firm. Of these, 170 usable questionnaires were received, representing a $33,7 \%$ return. ${ }^{8}$ In addition to the usable questionnaires, several letters/memoranda were received explaining certain aspects of the problem investigated. The breakdown of the participant firms, using the Stock Exchange classification as an index, appears in Table 1. Responses were received from firms in all sectors, with Industrial Holding/Conglomerates heading the list and Mining in second place. These two sectors are also the largest in terms of the number of firms per sector listed on the JSE.

The questionnaire contained three sections. The first section investigated the goal structure of the firms, and consisted of 26 questions (statements) representing a variety of aspects of goals and the goal structure of firms,

Table 1 Distribution of participating firms by in. dustrial activity

\begin{tabular}{lrr}
\hline \multicolumn{1}{c}{ Industries } & Number & $\%$ \\
\hline Mining & 19 & 11,2 \\
Banks and financial services & 10 & 5,9 \\
Insurance & 3 & 1,8 \\
Investment trusts & 1 & 0,6 \\
Property & 4 & 2,4 \\
Industrial holdings/Conglomerates & 22 & 12,9 \\
Beverages and hotels & 2 & 1,2 \\
Building and construction & 16 & 9,4 \\
Chemicals and oils & 6 & 3,5 \\
Clothing, footwear and textiles & 6 & 3,5 \\
Electronics & 2 & 1,2 \\
Engineering & 16 & 9,4 \\
Fishing & 3 & 1,8 \\
Food & 8 & 4,7 \\
Furniture and household & 3 & 1,8 \\
Motor & 10 & 5,9 \\
Paper and packaging & 8 & 4,7 \\
Pharmaceutic and medical & 3 & 1,8 \\
Printing and publishing & 2 & 1,2 \\
Steel and allied & 4 & 2,4 \\
Stores & 3 & 8,2 \\
Sugar & 2 & 1,8 \\
Tabacco and matches & 1,2 \\
Transportation & 3 & 1,8 \\
Total & 10 & 100,3 \\
\hline
\end{tabular}

with special reference to wealth maximization and social responsibility, as well as the relation between them. Most of the questions were phrased by means of a statement requesting the participants to select one of five possible responses to each question: strongly agree, agree, uncertain, disagree and strongly disagree. In a space provided, executives were invited to make additional written comments on each statement. An exceptionally good response to these questions was obtained. Some of these comments are also reported.

The main advantage of the modus operandi as described, is that it is simple and direct, thus easily understandable. However, a serious point of criticism may be that the possibility exists that it is not the respondent's personal opinion that is being tested, but rather his agreement with the statements per se. For the sake of brevity, 'strongly agree' and 'agree' responses were combined, as were the 'strongly disagree' and the 'disagree' responses, thus eliminating the effect of the 'uncertain' and 'nonresponses'.

The second section of the questionnaire was aimed at gathering personal information on executives themselves: their position in the firm, type of education/qualifications, number of years taken to obtain these qualifications and the number of years of business experience. The third section canvassed the opinions of executives on a statement relating to wealth maximization as a primary goal.

The size distribution of the participant firms in terms of depreciated book values appears in Table 2. Using size as a variable, a cross tabulation was made in order to determine whether firms of all size-categories agree/disagree with the statements posed in the questionnaire. For analytical purposes the responding firms were rather arbitrarily classified in two groups, namely 'small-sized' firms with assets of less than R 100 million $(n=108)$ and 'large-sized' firms $(n=62)$ with assets of more than R100 million.

Table 2 Distribution of participating firms by size

\begin{tabular}{ccc}
\hline Size of total assets (books values) & Number & $\%$ \\
\cline { 2 - 3 } R1 - R $50 \mathrm{~m}$ & 76 & 44,7 \\
R $50-$ R $100 \mathrm{~m}$ & 32 & 18,8 \\
R $100-$ R $150 \mathrm{~m}$ & 20 & 11,8 \\
R $150-$ R $200 \mathrm{~m}$ & 7 & 4,1 \\
R200 - R250m & 12 & 7,1 \\
R250m plus & 23 & 13,5 \\
Total & 170 & 100 \\
\hline
\end{tabular}

Specific information on the position, business experience and qualifications of the respondents is given in Tables 3, 4, 5 and 6 . Table 3 indicates the position of the respondents in the firms. Without any exception only senior executives completed the questionnaires. The average number of years of business experience of the executives is 24,3 years (Table 4). Academic and professional qualifications are summarized in Table 5 . It appears that $32,3 \%$ of the respondents hold business management qualifications as indicated; $26,5 \%$ have accounting qualifications; $15,3 \%$ engineering/technical 
Table 3 Distribution of respondents by position

\begin{tabular}{lcc}
\hline \multicolumn{1}{c}{ Position of respondents } & Number & $\%$ \\
\hline $\begin{array}{l}\text { Category } 1 \\
\text { Chief executive/managing director/ } \\
\text { group managing director/top executive/ } \\
\text { general manager/director }\end{array}$ & 101 & 59,4 \\
$\begin{array}{l}\text { Category } 2 \\
\text { Chairman/chairman and managing director }\end{array}$ & 33 & 19,4 \\
$\begin{array}{l}\text { Category 3 } \\
\text { Financial manager/financial director/ } \\
\text { senior accountant }\end{array}$ & 14 & 8,2 \\
$\begin{array}{l}\text { Category 4 } \\
\text { Secretary/group secretary }\end{array}$ & 16 & 9,4 \\
$\begin{array}{l}\text { Category 5 } \\
\text { Corporate planner/management services }\end{array}$ & 3 & 1,8 \\
Category 6 \\
Sundry: Different functional managers, \\
e.g. personnel, marketing \\
\begin{tabular}{l} 
Total \\
\hline
\end{tabular}
\end{tabular}

Table 4 Distribution of respondents by years of business experience

\begin{tabular}{crr}
\hline Years of business experience & Number & \multicolumn{1}{c}{$\%$} \\
\hline $1-5$ & 2 & 1,2 \\
$6-10$ & 9 & 5,3 \\
$11-15$ & 22 & 12,9 \\
$16-20$ & 28 & 16,5 \\
$21-25$ & 35 & 20,6 \\
$26-30$ & 37 & 21,8 \\
$31-35$ & 14 & 8,2 \\
$36-40$ & 14 & 8,2 \\
$41-45$ & 6 & 3,5 \\
$46-50$ & 2 & 1,2 \\
$50+$ & 1 & 0,6 \\
Total & 170 & 100 \\
\hline
\end{tabular}

Table 5 Distribution of respondents by academic qualifications

\begin{tabular}{lcc}
\hline \multicolumn{1}{c}{ Academic or professional qualifications } & Number & $\%$ \\
\hline $\begin{array}{l}\text { Business management qualifications } \\
\text { B.Com./M.Com. plus MBA, MBL }\end{array}$ & 13 & 7,6 \\
$\begin{array}{l}\text { B.Sc. plus MBA, MBL } \\
\text { Other business management qualifications }\end{array}$ & 13 & 7,6 \\
e.g. Bankers' diplomas etc. & 29 & 17,1 \\
Accounting qualifications & & \\
Chartered accountants & 33 & 19,4 \\
Business management/accounting combined & 12 & 7,1 \\
Engineering/technical degrees/diplomas & & \\
B.Sc., technical qualifications & 26 & 15,3 \\
Legal qualifications & & \\
B.A. LL.B., B.Com. L.L.B. & 8 & 4,7 \\
Degrees in arts & & \\
B.A., M.A. & 12 & 7,1 \\
Matric only & 24 & 14,1 \\
Total & 170 & 100 \\
\hline
\end{tabular}

education of some kind; $4,7 \%$ have a legal background; $7,1 \%$ are arts graduates, while $14,1 \%$ of the respondents have no formal tertiary education. The number of respondents with matric only is also confirmed in Table 6 which indicates the number of years of post-matric study. The mean is 4,81 years, median 5,00 years and the mode 6,00 years.

Table 6 Distribution of respondents by number of years of post-matric study

\begin{tabular}{crr} 
Number of years of post-matric study & Number & $\%$ \\
\hline Nil & 24 & 14,1 \\
2 & 5 & 2,9 \\
3 & 9 & 5,3 \\
4 & 25 & 14,7 \\
5 & 34 & 20,0 \\
6 & 36 & 21,2 \\
7 & 12 & 7,1 \\
8 & 14 & 8,2 \\
9 & 11 & 6,5 \\
Total & 170 & 100 \\
\hline
\end{tabular}

Together with the appropriate theoretical background, the following empirical findings will now be discussed: firstly, the response on goals of the firm in general, with special reference to primary and secondary goals and the requirements that such goals must meet; secondly, the effect of the separation of ownership and control on the goal structure of firms; thirdly, the response regarding the concept of wealth maximization; and finally, the response regarding a series of alternatives or coobjectives, such as: growth, maximum turnover, satisfactory results, security and safety, and social responsibility. Throughout the discussion the viewpoint will be that of the financial manager, seeking an objective rational goal that can also serve as a decision-criterion for financial decision-making. Rational decisions presuppose welldefined goals and before proceeding with the analysis it is therefore necessary to agree upon the goals towards which financial decisions should be aimed.

The research findings are contrasted with comparable research findings in the United States, performed by Charles P. Edmonds III and John H. Hand. ${ }^{9 .}$ pp.75-81 This comparison enables the reader to draw some interesting conclusions about the opinions of some South African and American executives who participated in the surveys.

\section{Goals of the firm in general}

Primary and secondary goals: requirements that goals must meet

Generally speaking, man endeavours to conduct his affairs in a purposeful manner, that is, he seeks to be guided by general goals. By the word 'goal' is understood the basic sense of direction towards which a group's activities are directed. Persons in a group context will maintain their own personal goals and aims, but collective action will be based on the goals of the group. The goals of the firm must not be confused with the personal goals of the group which may be highly variable and necessarily subjective. 
The basic function of general management is to guide the firm to achieve its goals. This includes determining the goals of the firm and modifying these under the influence of current economic, social, political, legal and other pressures. Top-management decisions in this regard are of great importance and in many respects they have in their control the very survival of the free enterprise system in one way or another.

A distinction can be drawn between primary and secondary goals. Primary goals are mainly profitoriented and will normally always be pursued to ensure the survival of the firm. Secondary goals are goals that support or lead towards the achievement of primary goals.

Primary goals must meet specific requirements. Firstly, primary goals must be autonomous, the permanent unalterable raison d'être of the firm, thus a primary driving force. Secondly, primary goals must not be a vehicle for achieving other goals; they must not be derived from other goals. In addition to the above two requirements of primary goals, finance as a functional area of business economics imposes further additional requirements on goals per se. Should alternative courses of action exist, the pursued goals must enable the decisionmaker to differentiate between alternatives in terms of their economic-financial desirability. It must also be possible to rank alternatives in terms of descending economic-financial acceptability. For the purpose of finance, a goal (or decision-criterion) is required that allows the decision-maker to differentiate between courses of action. This goal must embrace the amounts, time patterns and risk of cash flows associated with alternatives. Thus, the goal of finance must also fulfil the function of an operational decision-criterion, that is, a goal which can be used as guideline in practical situations.

\section{The survey}

A number of possible goals were listed in the questionnaire, requesting the respondents to indicate whether they regarded them as primary or secondary goals for their firms. Both concepts were explained in the questionnaire. Table 7, particularly questions 1 to 9 , includes information on a constellation of goals which have, at some time or another, been described in the theory of the firm as indicative of the primary driving force of the firm.

Several inferences may be made from the information contained in Table 7 , in which some of the data of the Edmonds and Hand survey (USA) are also indicated. South African executives responding to this survey regard profit maximization; maximizing the rate of return (profitability) on equity capital; maintenance of liquidity and solvency; and maximization of earnings per share and growth as primary objectives, all scoring more than $50 \%$ of the responses (questions $1,4,5,8$ and 9). It seems then that despite the phenomenon that in certain circles profit maximization has become increasingly an unacceptable word, this concept of the goal of the firm cannot be ignored, denied or replaced in the capitalistic system. The $91,8 \%$ listing of profit maximization and $90 \%$ for maximizing the rate of return on equity capital as primary objectives are therefore well in line with the basic philosophy of the free enterprise system. Although highly ambiguous and subject to serious criticism, earnings per share $(79,4 \%$ rating as a primary objective) can be judged as a reflection of the consequences of profit and rate of return maximization. The high rankings of liquidity and solvency $(84,1 \%)$ and growth $(68,2 \%)$ as primary goals were not expected because they do not seem to meet the requirements of autonomous goals. Question 3, referring to maximizing the market price per share - a possible parameter of the wealth maximization goal - was listed by only $31,8 \%$ of the executives as a primary goal. A possible reason for this low score may be a misunderstanding or different interpretation of the meaning of the concept of wealth maximization. Comparing the South African data on the first seven questions with those of the Edmonds and Hand survey, a totally different ranking of primary objectives is found, particularly on maximizing market price per share, social responsibility and a good company image. In the Edmonds and Hand survey, objectives such as maximizing the market price per share $(67 \%)$, social responsibility $(73,3 \%)$, a good company image $(72,3 \%)$, profit maximization $(83,7 \%)$, rate of return maximization $(95,7 \%)$ and continuity $(84,2 \%)$, were all listed as primary driving forces of the firm. The only exception was maximum turnover - only $18,7 \%$ deemed sales maximization a primary goal.

With size as an independent variable, a crosstabulation was done in order to ascertain if there were any differences between the answers of executives of small-sized and large-sized firms. Except for the tendency that executives in large-sized firms place more emphasis on market price per share as a primary goal, no other significant conclusions could be drawn.

In the questionnaire space was left open for the listing of any 'other' primary or secondary goals. As secondary 'other' goals, most executives referred to the human side of the firm, stressing the necessity of sound labour relations. Primary 'other' goals included philosophies relating to the possibilities of earning profits.

The following responses were typical of primary 'other' goals (question 10):

- To establish a sound base in the basic . . . industry from which the group can grow. (Specific industry deleted.)

- Specified minimum return on shareholders' funds and balancing risk and return.

- Growth in earnings per share is a primary goal, other growth goals are secondary.

- A real growth in dividends to at least equal the growth in GNP for the . . . sector.

- Achievement of a specified gearing ratio and to remain independent.

- Lowest cost competitor; market dominance.

- Growth by merger and additions to product range.

- Product rationalization. To improve range and profitability.

- Maximizing the return to shareholders, that is capital appreciation of shares plus dividend payouts over the long term.

- Maximizing the return on total assets.

The following responses were typical of secondary 'other' goals:

- Retention of staff, via compensation, motivation, continuing education and attractive environment. 
Listed below are a number of possible goals of a firm. At one time or another each of those listed in geen described as a primary goal

1. Profit maximization (lowest costs/inputs; highest revenue/output)

2. Maximum turnover

3. Maximizing market price per share

4. Maximizing the rate of return on equity capital

5. Maintenance of liquidity and solvency (in order 10 maintain continuity and survival)

6. Social responsibility

7. A good company image

8. Maximization of earnings per share

9. Growth as a goal (example: growth in market share, sales volume, total assets, earnings per share, ...

10. Other possible goals (see text)

11. In cases where there are multiple objectives, do you agree/disagree that firms can achieve all of them in the decision-making in the long run?

12. The success of a firm must not be judged in terms of maximizing results, but rather "satisfactory" results. The opinion exists that 'satisfactory' results (e.g. 'satisfactory' target rate of return, profits, .. ) are more typical of a firm's behaviour than maximum results (maximum results such as maximum rate of return, profits, ....)

13. A distinction can be drawn between owner-controlled and manager-controlled firms. The phenomenon of 'capitalism without capitalists' has come into being. Do you agree/disagree that in the short run actions of (professional) management may come into conflict with the wishes of shareholders?

14. For the firm(s) of which you have had personal experience, do you agree/disagree that 'maximization of shareholders wealth' is descriptive of their primary long-run objective?

15. The management of most firms is reluctant to emphasize profit and wealth maximization publicly.

16. It is argued that profit maximization is a short-term approach and that 'the desire for secure profits' is an important long-term objective. Explanation: 'secure profits': profits that can be achieved with a minimum of business and financial risk

17. The growth of firms is important for management because thereby the members of management gain prestige, personal satisfaction from the successful growth of the firm with which they are connected, more responsible and better paid positions, and wider scope for their ambitions and abilities.

18. The goal of the firm is the maximization of the market value of its own ordinary shares, subject to whatever constraints, legal or moral, exist in the firm's environment.

19. The firm and its managers are, after all, subject to the same moral codes which control all the other activities of society. The law requires certain things of us. But beyond this lies the ethical, which, in the real sense, fills the gap between the law and the actual decisions taken by management, its actual behaviour. And in this area management is guided by its own sense of right and wrong. Conceived of in this way, the firm, in meeting social obligations, allows a considerable measure of managerial discretion.

The following statements describe the possible relationship between the objectives of wealth maximi zation of shareholders and the objective of being socially responsible. Indicate whether you agree or disagree with each statement.

20. The objectives of wealth maximization and social responsibility are basically contradictory

\begin{tabular}{rrrr}
16,5 & 78,2 & 9,5 & 80,9 \\
76,5 & 19,4 & 70,8 & 16,8 \\
83,5 & 10,6 & 87,5 & 6,6 \\
27,7 & 61,2 & 44,5 & 44,0 \\
37,6 & 50,0 & $*$ & \\
\hline
\end{tabular}

1 As performed by the authors as described.

${ }^{2}$ Charles P. Edmonds and John H. Hand, 'What are the Real Long-run Objectives of Business?', Business Horizons, Vol, 19, Dec. 1976, p.77.

South African United States

\begin{tabular}{|c|c|c|c|}
\hline$\underset{\% \%}{\text { Agree }}$ & $\begin{array}{c}\text { Disagree } \\
0 \%\end{array}$ & $\underset{0 \%}{\text { Agree }}$ & $\begin{array}{c}\text { Disagree } \\
\%\end{array}$ \\
\hline 91.8 & 5,3 & 83,7 & 10,1 \\
\hline 25,9 & 65,9 & 18,7 & 70,4 \\
\hline 31,8 & 63,5 & 67,0 & 18,6 \\
\hline 90,0 & 8.2 & 95,7 & 1,0 \\
\hline 84.1 & 11,8 & 84,2 & 7,6 \\
\hline 16,5 & 79,4 & 73,3 & 16,2 \\
\hline 42.9 & 53,5 & 72,3 & 14,4 \\
\hline 79,4 & 17,6 & * & * \\
\hline 68,2 & 28,8 & * & * \\
\hline 14,7 & 8,8 & * & * \\
\hline 86,4 & 7,7 & * & * \\
\hline 55,3 & 36,4 & * & • \\
\hline 71,8 & 21,2 & * & • \\
\hline 78,3 & 15,9 & 61,8 & 29,7 \\
\hline 42,3 & 49,4 & 37,8 & 49,8 \\
\hline 60,6 & 32,9 & * & * \\
\hline 84,1 & 11,2 & * & * \\
\hline 51,2 & 37,0 & - & $*$ \\
\hline
\end{tabular}

21. Social responsibility is simply another prerequisite that management must consider in trying to satisfy the wealth maximization objective

22. Social responsibility and wealth maximization are among many objectives that management pursues

23. Owing to increased emphasis on moral and social responsibility, management now places less emphasis on stockholder wealth than it did, say, ten years ago

24. If your firm were to avoid its social responsibility, such a step would lead to the failure of your firm (failure - decrease in turnover, rate of return, etc.). Do you agree/disagree with this statement? 
- To attract and retain top-class management.

- To maintain continued advancement and education of staff to build stability.

- To promote the future security of all employees.

- Sound labour relations.

- Fair dealings with customers, suppliers and consumers.

Many executives considered questions $1,3,4$, and 8 of Table 7 to be synonymous. Based on the answers to questions 1 to 10 and more particularly on the comments of executives on each question, it seems that primary and secondary goals can change depending on the circumstances in which a company finds itself working at any time during its life. Some executives see maintenance of liquidity and solvency, social responsibility and a good company image as being primary goals at all times ... but whether the maximization of the rate of return on equity capital or growth as a goal should be a primary or secondary objective can depend very much on circumstances. For example, with the launching of a new product or a new product line, or at the time of the introduction of a product into the market, growth could be a prime objective as a means of establishing either the new product or the company in a new market; or, alternatively, the possibility exists that the firm's main consideration could be to maximize the rate of return on equity, even if it encounters a reduction in growth, turnover and profit maximization.

On the basis of the information obtained from questions 1 to 10 only, no conclusion could be reached on the validity of the wealth-maximization hypothesis (question 3) as a primary goal of the firm.

In order to ascertain whether multiple goals could be in conflict with each other, question 11 was included in the questionnaire. More than $86 \%$ of the executives agreed that in cases of multiple objectives, firms can still attend to all of them in the decision-making process in the long run. Only $7,7 \%$ of the executives did not share this opinion.

Typical responses of executives agreeing with the statement were as follows:

- Conflict between objectives can arise and these should not be set independently of each other.

- Provided a prime aim is chosen subject to acceptable constraints for others, e.g. maximize profits subject to wage policy constraints. Trade-offs to be found.

- Many objectives lead from one to the other and an effective organization can realize multiple objectives.

\section{The separation of ownership and control and its im. plications on the goal structure of firms}

During the free capitalistic era (up to circa 1870) the provision of capital (ownership) and the management of firms were exclusively centred in the hands of the same person. The interests of owners and management were the same, fundamentally aimed at profit-maximization.

Even at present it is often assumed that firms operate solely for the benefit of their owners. This statement may apply in the case of sole proprietorships and partnerships, but since about 1875 with the rise of large-scale industry and the merging of firms, as well as the increasing importance of the company as a form of business enter- prise, significant changes have occurred in this domain. An increasing separation of management and ownership has occurred in the capitalistic system - one of the most important developments in the history of the capitalistic system. Whereas the provision of capital and management had previously been united in the hands of the same individual, the situation has now changed in that a group of professional managers have emerged, whose position is not determined by ownership and whose motives and incentives are often not the same as those of the classical entrepreneur. ${ }^{10} \mathrm{~A}$ distinction can thus be made between owner-controlled and manager-controlled firms.

The consequences of the separation of ownership and management are far reaching. The individual owners (shareholders) do not interfere with the daily management of the firm. No longer do the real owners set the goals and policies of manager-controlled firms - this is done by hired professional managers who are not necessarily shareholders or joint proprietors. The result of this separation of ownership and management is that the suppliers of the risk-bearing capital have lost their influence on the goals of the firms and they are playing an increasingly passive role. Some shareholders effect a link with the firm only when they expect dividend payments.

The question has often been posed whether professional management pursues policies which are in line or at odds with the interests of shareholders. Two fundamental views can be reported: one based on possible conflict between the parties, and the other on uniformity and similarity of interests.

Depending on the extent of their influence on shareholders and the form of markets within which their firms operate, professional managers may pursue goals which may not be in the best interest of shareholders. Berle and Means questioned this complication nearly fifty years ago:

'But have we any justification for assuming that those in control of a modern corporation will also choose to operate in the interest of the stockholders? The answer to this question will depend on the degree to which the self-interest of those in control may run parallel to the interest of the ownership and, in so far as they differ, on the checks of the use of power which may be established by political, economic, or social conditions. ${ }^{11 . p p .113-114}$ Berle and Means believe when ownership is separated from control, the shareholders ' . . . have surrendered the right that the corporation should be operated in their sole interest . . , $11,0.311-312$

Not only must the firm be managed in the best interest of those who are in control but also in the interest of the community at large. 11, p.312: $10 . p p .8-10$ With regard to the phenomenon of manager-controlled firms and the possibility of a clash of interest with the shareholders, Reid tested the following hypothesis:

'The more actively that large, publicly held firms merge, the more they tend to be oriented to furthering managers' interests rather than stockholders' interests. ${ }^{12, p .154}$ Reid found in general ' . . . that those firms which merge tend to be more oriented to managers' interests than to stockholders' interests - appears to have been true for large American industrial firms ..., 12, p.168 
Reid ${ }^{13, p .48}$ questions whether external growth is the best method of growth and maintains that some mergers are not made for economic reasons, but merely to satisfy the ego of an individual manager - or even to help an incompetent manager to keep his job by confusing stockholders.

In contrast to the opinions of Berle and Means, and the empirical findings of Reid, Werkema ${ }^{14 . p p .55-68}$ argues that the best interests of professional management may not necessarily be in conflict with the wishes of shareholders. According to Werkema a group of professional managers may use more objective data and criteria in the decisionmaking process than would individuals. Therefore, argues Werkema, it would be more difficult for individual members of a group to allow personal preferences to play a part in the management process. Such personal preferences will remain in the background. When a group of professional managers takes decisions, one of the requirements is that a measurable goal must be pursued. With certain exceptions then, professional managers will take decisions which are in the best interests of the firm and its owners, because they do not want to endanger their careers. Their actions will therefore be maximizing, identified by the pursuit of maximum profits in the long run. Should the thesis be accepted that the interests of management and shareholders are complementary, management can be expected to seek the interest of shareholders and act accordingly. Whether this applies in all circumstances, still remains an open question.

The separation of ownership and management in the capitalistic system has also coincided with the unification of labourers in trade unions, who thereby obtained a greater voice in various matters regarding the internal affairs of the firm. The fusion of labourers in trade unions, the emancipating Christian, humanistic, and social attitudes, and changing philosophies toward life, together with the separation of ownership and management, have directed a shift from the firm's pure economic responsibility to a more social responsibility. It may justly be claimed that an evolution from the firm's profit goal to a social goal has occurred, marking the appearance of a new management ideology.

'In this ideology', Solomon argues, 'the ownermanager of the classical system, interested solely in his own gain, has been replaced by the professional manager who serves as trustee, not only for owners but for all parties connected with the enterprise, including employees, customers, suppliers, creditors, the government, the general public, and management itself. In this newer ideology, profit-maximization is regarded as unrealistic, difficult, inappropriate, and immoral. In its place we have a constellation of objectives including service, survival, sales, personal satisfaction, and satisfactory profits. Businessmen who occasionally lapse into talk about profit-maximization are chastised for it.'15, p.16

With the above changes in the capitalistic system in mind, statements 13 and 15 were tested as shown in Table 7. Statement 13 was formulated as follows: 'A distinction can be drawn between owner-controlled and managercontrolled firms. The phenomenon of "capitalism without capitalists" has come into being. Do you agree/disagree that in the short run actions of (professional) management may come into conflict with the wishes of shareholders'? Approximately $72 \%$ of all respondents said that in the short run there may be a conflict in interests between professional management and shareholders. The position is quite different in the long run. There are reasons to believe that professional management is not free to act in an entirely discretionary way. Taking the personal comments into account, it seems that in the long run managers do identify with the wishes of the broad spectrum of shareholders, although to an unagreed extent. Comparable data were not given by the Edmonds and Hand survey.

Since the profit concept and profit-maximization seem to have come under attack increasingly in recent years, statement 15 tested opinions on firms' disclosure of profits and wealth. Approximately $42 \%$ of the executives agreed that the management of most firms is reluctant to emphasize profit and wealth maximization publicly, $49,4 \%$ disagreed and $8,3 \%$ were uncertain. A cross-tabulation of this statement, using size as an independent variable, indicated that it was mostly small-sized firms which endorsed this statement (that is firms with assets of less than R100 million). Similar responses were reported in the Edmonds and Hand survey: $37,8 \%$ of the participants agreed and $49,8 \%$ disagreed that the management of most firms is reluctant to emphasize profit publicly.

Arguments supporting disagree responses, were the following:

- There is a tendency to refer to 'earnings' rather than 'profit'.

- Most public companies seem quite happy to boast about profit increases either in their annual report or media announcements.

- Such management does not achieve its targets.

Those who agreed with the statement produced arguments like the following:

- 'Profit' can be an emotional word, usually derogatory. Normal accounting conventions do not even define profit. What is profit? Historical versus replacement cost argument.

- Capitalism has developed a guilt complex.

\section{Wealth maximization as a goal}

The major hypothesis underlying this research - the assumption that shareholders' wealth maximization is representative of the goal of the firm - may, according to Levy and Sarnat ${ }^{6, p p .526-528}$ be alternatively formulated as either (a) the maximization of share prices; or (b) the maximization of the value of the equity; or (c) the maximization of the firm's total market value. Using Levy and Sarnat's alternative formulation of the wealth maximization goal as a basis, questions based on the alternative approaches were included in the questionnaire by means of statements 3, 14, 18 and, to a lesser extent, statement 4.

Question 3, a possible parameter of the wealth maximization hypothesis, canvassed the opinions of the respondents on whether maximization of the market price per share can be listed as a primary goal. Of the South African executives who participated, only $31,8 \%$ regarded maximization of market values as a primary goal; $63,5 \%$ 
disagreed, thus rating it as a secondary goal. On this question there is no agreement whatsoever between the answers of the South African executives and those reported by Edmonds and Hand. Sixty-seven percent of the Edmonds and Hand respondents deemed maximizing of market price per share to be a primary goal; only $18,6 \%$ disagreed. A close investigation of the answers to these questions, and more particularly of the personal comments on question 3 , indicates that the South African executives are probably not familiar with the alternative ways of expressing the wealth maximization goal - this despite an explanation supplied in a footnote in the questionnaire - or that they do not pursue the goal of wealth maximization.

Although not an exact formulation of the wealth maximization goal, the responses to question 4 - that is, whether the maximization of the rate of return on equity is a primary goal - were not unexpected. Ninety percent of the South African respondents rated this as a primary goal, while nearly $96 \%$ of the executives who participated in the Edmonds and Hand survey agreed with this statement.

In order to establish whether maximization of shareholders' wealth is descriptive of firms' primary long-term objectives, statement 14 was included in the questionnaire. This statement received the support of $78,3 \%$ of the South African respondents, with only $15,9 \%$ not supporting the statement. In the Edmonds and Hand survey, less support (only $61,8 \%$ in favour) was given to the wealth maximization hypothesis than in the South African case. On balance the response to this statement, more particularly that of the South African executives, seems to support quite strongly the principle of wealth maximization as explained in basic finance textbooks.

The next statement on wealth maximization - the goal of the firm is the maximization of the market value of its own ordinary shares subject to whatever constraints, legal or moral, exist in the firm's environment (statement 18) - did not receive as strong support as did question 14. Only $51,2 \%$ of the South African executives in question endorsed this statement with a substantial $37 \%$ in disagreement. It is interesting to note that more respondents were uncertain on statement $18(11,2 \%)$ than in the case of question $14(5,9 \%)$. No question comparable to statement 18 was set in the Edmonds and Hand survey.

A cross-tabulation of questions 14 and 18 with the size of the firm produced some interesting findings. The larger the firm, the stronger the tendency to approve the wealth maximization goal. Nearly $64 \%$ of executives from large-sized firms agreed with the wealth maximization statement, in contrast to only $44 \%$ of executives from small-sized firms.

Some of the comments of those whose replies to statements 14 and 18 supported the hypothesis on wealth maximization (with provisos) follow:

- Provided a long-term view is considered, plus all other applicable constraints.

- In terms of discounted cash flow values and if all parties are included.

- Our professional skills produce long-term 'wealth'.

- This is a reflection of the performance of a company's management.

- This is the basic understanding between management and shareholders.

Typical opinions of executives who disagreed with statements 14 and 18 were the following:

- We aim to provide satisfactory returns to shareholders and to safeguard the value of the shareholders' interest in the long term.

- Not a goal, but a consequence of the successful pursuit of many objectives.

- The company does its level best to make profits; the market judges the results of the company and establishes a share price.

Judging by the responses to and comments on questions $3,4,14$ and 18 , it appears that the wealth maximization hypothesis considered in this survey is applicable to listed firms on the JSE which participated in the survey.

\section{Growth as a goal}

In recent times it has often been stated that management's prime function is the maximization of the physical size of the firm instead of profits and shareholders' wealth. Growth as a goal may be expressed in terms of market share, increased economic power, or in absolute monetary terms (such as the value of fixed assets, total assets, total net income, earnings per share, or size of retained profits).

In response to question $9,68,2 \%$ of the executives rated growth as a primary goal, but the growth of firms is also important from a management angle. Opinions on the growth goal were further tested by means of statement 17: 'The growth of firms is important for management because thereby members of management gain prestige, personal satisfaction from the successful growth of the firm with which they are connected, more responsible and better paid positions, and wider scope for their ambitions and abilities.' Strong support was voiced by the participants for this approach: $84,1 \%$ agreed, $11,2 \%$ disagreed and only $4,1 \%$ were uncertain. The response from both small-sized and large-sized firms to statement 17 did not reveal any significant variance.

Those who agreed with the statement on growth as a goal commented as follows:

- Provided there is growth in all aspects of the business, including personnel.

- Companies in a group have growth targets in view of improving shareholders' wealth.

- Growth is important to recruit suitable staff.

- Achievement is a major motivator for the majority of professional managers.

Comment from one of those who disagreed:

- An executive's prime aim is a sound business with continued employment for many people and not for personal prestige.

No comparable information for United States firms was available from the Edmonds and Hand survey. The general agreement with the statements on growth may be explained in that the participants in the survey do receive monetary and non-monetary rewards should they maximize the growth of the firm. However, taking the requirements of autonomous goals into account, growth may not be listed as an independent and autonomous goal, but only as a condition for achieving the primary profit and wealth goals. 


\section{Maximum turnover}

William Baumol ${ }^{16}$ developed a model of firms' behaviour under conditions of oligopolistic competition, stating that in an oligopolistic market structure the management of firms will be more inclined to maximize total turnover, instead of profits.

The existence of a minimum profit requirement must be an essential element in the maximum turnover hypothesis, otherwise this optimum is unattainable. To obtain meaningful answers to the maximum turnover hypothesis (question 2), firms operating under conditions of oligopolies should have been identified and treated separately. This was, however, not feasible. Without taking the possibility of oligopolies into account and taking as a base the total responses $(n=170)$, only $25,9 \%$ of the participants considered sales maximization as a primary goal. These opinions are in line with the Edmonds and Hand findings where only $18,7 \%$ felt that having the largest possible turnover is a basic corporate objective.

The assumption regarding turnover as an autonomous goal seems to be completely unfounded; this explains the responses to question 2 . Increasing the market share and ignoring profit considerations may pave the way to failure for the firm. Should the turnover criterion dominate the profit criterion, serious distortions may occur in the production programmes of multiproduct firms. It may be possible, however, for professional management to pursue turnover goals, because their remuneration and prestige may be dependent on this criterion.

\section{Security and safety}

Several economists present a modified view of the firm's economic behaviour, giving security and the continuity of the firm meaning as an autonomous goal. Rothschild $^{17, p p .400-464}$ refers to 'the desire for secure profits' as an important goal of the firm that may not be ignored, thus presenting the motive of 'security maximization' beside profit maximization as the main goal of the firm.

The profit maximization goal as such is also rejected by Gordon ${ }^{18 . ~ p p .265-288 ~ o w i n g ~ t o ~ u n c e r t a i n t y . ~ I n c o m p l e t e ~ i n-~}$ formation and uncertainty oblige the firm to stabilize relations with its suppliers, customers, competitors and other parties concerned. Fellner ${ }^{19}$ is also of the opinion that safety and the urge for security take a more or less autonomous position beside the pursuit of profits. By means of agreements on prices the firm may hedge itself against possible mistakes in the planning and decisionmaking process. Agreements on prices may be common with oligopolies.

Safety and security may be interpreted in terms of the maintenance of liquidity and solvency.

With all the above in mind, statements 5 and 16 were included in the survey. Both the South African and United States executives deemed the maintenance of liquidity and solvency of great importance as a primary goal (question 5): approximately $84 \%$ of the participants of both surveys agreed with the liquidity and solvency statement. Only $11,8 \%$ of the South African and $7,6 \%$ of the Edmunds and Hand participants disagreed. Statement 16 is based on the view of Rothschild - the hypothesis that profit maximization is a short-term approach and that 'the desire for secure profits' is an important long-term objective. This statement was supported by
$60,6 \%$ of the South African participants, with $32,9 \%$ in disagreement. The importance of the concept of 'secure profits' seems to be widely recognized. A crosstabulation using size as a variable confirmed the above conclusions. No comparable question was reported in the Edmonds and Hand survey.

Comments by respondents on agree responses on security maximization included the following:

- There should be a balance between risk and return.

- Secure profits lead to the long-term survival of the firm.

- In the South African environment, 'secure profits' are essential.

Comments of those who disagreed:

- Believe as a principle that profits should be 'maximized' to secure long-term future.

- In our business 'secure' tends to equate with 'restricted', e.g. our cost plus contracts with . . . for coal (name deleted). Ideal is a balance of high and low risk and returns.

Although the argument for safety and security sounds convincing as these lead to the independence of the individual firm, which is of fundamental importance for the maintenance of the competitive system, it cannot by itself be considered the raison d'être of the individual firm.

\section{'Satisfactory' behaviour}

Owing to the complexity of the decision-making process, the high cost of information, the limitations of man to evaluate a large number of alternatives, Simon and March ${ }^{20, p .140}$ suggest that the success of firms must not be measured in terms of the maximization hypothesis, but rather on the basis of 'satisfactory' results (for example, 'satisfactory' profits, turnover). This hypothesis (statement 12) received the support of $55,3 \%$ of the South African executives who participated. However, it also drew substantial opposition with $36,4 \%$ of the participants opposing the statement. No comparable question was set in the Edmonds and Hand survey. Numerous comments were received on this statement.

Some comments from executives who opposed the hypothesis on satisfactory profits were the following:

- Satisfactory results reflect an 'average' company and performance and limited achievement.

- Although business firms are measured by targets (budgets, plans, etc.) the long-run successful firm is that which outperforms others by maximizing profits.

- Satisfactory results lead to complacency.

- If one adopts the 'secure profit' approach, lower returns result. Risk taking is necessary for long-term profit optimization.

- It must be a company's objective to maximize its performance.

- The firm must excel - if you do not, you will never be better than average.

Some of those who agreed with the hypothesis argued:

- Planned satisfactory results indicate good control.

- True criterion. Satisfactory, hence improved results on an ongoing, year-in, year-out basis. 
Social economic goals: social responsibility of the firm

With changing ratiocinations in ethical and social spheres, certain pressure groups maintain that the firm has a primary responsibility toward the community and its employees. Apart from the conditional influences of ethical and social norms, this also has a goal-determining effect.

Judging from what has been said in books, articles and other writings on this topic, it is felt that the concept of social responsibility has suffered from a lack of definition as an issue and, as a consequence, discussion of the matter has been amorphous and ill-focused, causing serious differences in opinion.

According to far-leftist advocates of the doctrine of social responsibility, the firm must be seen externally as an organ serving the interests of the community. Thus, the goal of the firm is the promotion of the largest social economic productivity, and this accomplishment is the basis for measuring the firm's behaviour. Internally the firm is regarded as a labour community, serving everyone's interests equally. Great power is centred in the hands of management and should this power be used to maximize profits, the results will, according to the leftist doctrine of social responsibility, have a negative impact on the economy, the firm itself, and management. Only certain types of profit decisions are legal and decisions outside this 'limit' are viewed as socially irresponsible, if not illegal. This view of social responsibility is very close to unadulterated socialism.

For the purpose of this survey a detailed discussion of the different schools of thought on social responsibility is not required. It will suffice to say that the firm and its management have responsibilities to at least four groups in society. ${ }^{1, p p .439-441}$

In the first instance the responsibility is to the owners and shareholders who require a wise and profitable employment of their funds. Secondly, there is the inevitable responsibility to employees in regard to paying just wages, and several other human considerations such as job security and satisfaction, a favourable physical work environment, concern for their living conditions outside the firm, and numerous similar matters. Thirdly, there is the responsibility to customers whose wants must be satisfied with the best products at the lowest prices. A fourth group is the local community where the firm must support charitable institutions, paying attention to matters such as housing, avoidance of pollution, improved amenities in general and recreational facilities. Finally, the firm is responsible to society at large for the preservation of all the organs of the capitalistic system which make possible, inter alia, the improvement of living standards.

Statements 20 to 23 deal with social responsibility and wealth maximization. Of the South African respondents $78,2 \%$ disagreed that the two objectives are basically contradictory (statement 20). The figure for the United States sample is marginally more, approximately $81 \%$. Almost $77 \%$ of South African respondents agreed that the acceptance of social responsibility by business is a condition for maximizing shareholders' wealth (statement 21). The corresponding figure for the United States survey is $70,8 \%$. A high number of local respondents,
$83,5 \%$, agreed that social responsibility and wealth maximization are among the many objectives management pursues (statement 22). United States respondents felt this more strongly, where an impressive $87,5 \%$ agreed with the statement.

Quite remarkable were the responses to statement 23. Of the South African executives, only $27,7 \%$ agreed that owing to increased emphasis on moral and social responsibility, management now places less emphasis on stockholder wealth than it did some ten years ago, in contrast to the $44,5 \%$ agreement found by Edmonds and Hand. More South African respondents disagreed with statement $23(61,2 \%)$ than those in the Edmonds and Hand survey $(44,0 \%)$. Nearly $10 \%$ of the South African respondents were neutral (uncertain) about this statement, possibly indicating uncertainty among managers about the scope and nature of corporate social responsibility. Cross-tabulations with size as a variable confirmed the same pattern of answers. The lower percentage of South African respondents agreeing that management places less emphasis on shareholder wealth than it did ten years ago, may be attributed to a more conservative view on this matter. It is therefore regarded as wrong to overemphasize corporate social responsibility. This is also supported by the responses to statement 24 . About $50 \%$ of the respondents disagreed with the statement that if a firm were to avoid its social responsibility, this would lead to the failure of the firm.

The personal opinions of executives on statements 19 to 23 are grouped in Appendix 1.

In order to determine the relative importance of the responsibility of the firm and its management to all the different parties concerned in the firm's total business environment, executives were requested to rank society, government and national economy, creditors, customers, employees and shareholders. Table 8 indicates the ranking of the responsibilities of top management to the parties concerned.

Table 8 Ranking of the responsibilities of general management toward different parties concerned (expressed as a percentage)

\begin{tabular}{|c|c|c|c|c|c|c|c|}
\hline Ranking: & Parties concerned & 1 & 2 & 3 & 4 & 5 & 6 \\
\hline 5 & Society & 1,8 & 2,4 & 7,1 & 25,3 & 34,1 & 23,6 \\
\hline 6 & $\begin{array}{l}\text { Government and } \\
\text { economy }\end{array}$ & 0,6 & 1,2 & 2,4 & 7,6 & 35,3 & 47,1 \\
\hline 4 & Creditors & 1,8 & 3,5 & 9,4 & 40,0 & 21.2 & 18,2 \\
\hline 3 & Customers & 11.2 & 20,0 & 47,6 & 12,4 & 1,2 & 1,8 \\
\hline 2 & Employees & 8,8 & 59,4 & 20.6 & 4,7 & 0.6 & 0,6 \\
\hline 1 & Shareholders & 72,9 & 10,6 & 8,2 & 3,5 & 0,6 & 0,6 \\
\hline
\end{tabular}

An overwhelming $73 \%$ of respondents ranked shareholders first; followed by employees in the second place $(59,4 \%)$; then customers $(47,6 \%)$; creditors ranking fourth $(40,0 \%)$; society fifth $(34,1 \%)$; and finally government and the economy. More executives ranked government and the economy in sixth place $(47,1 \%$ ) than society $(23,6 \%)$. Ranking for the fifth place is rather close (society $34,1 \%$; government and economy $35,3 \%$ ). From the cross-tabulation it appeared that mostly smaller-sized 
firms ranked government and the economy higher than society.

On a agree-disagree basis, Edmonds and Hand found that executives felt their greatest responsibility is to shareholders $(89,3 \%)$; the second and third highest percentages were for employees and customers, with a $76,3 \%$ and $72,4 \%$ vote respectively, followed by society in the fourth place $(56,5 \%)$, with creditors taking fifth place $(48,8 \%)$. The government and economy were not included.

\section{Comments on the goal of shareholder wealth maxi- mization (Section C)}

Executives were asked to respond to the following statement: 'Top company executives may seek several objectives, but maximizing shareholder wealth is the primary long-run objective that motivates and guides their actions.'

Once again, an exceptionally good response was obtained. Most executives did not simply agree or disagree with the statement, and almost all qualified their responses in some way.

Twenty responses were selected either supporting or rejecting the above hypothesis. These are listed in Appendix 2 . On balance approximately $60 \%$ of the responses were in favour of the concept, the remaining $40 \%$ supporting other approaches.

\section{Conclusions}

It is possible that the results of this study and their interpretation have raised more questions than are answered. It is not the intention to claim answers on all statements investigated. However, it is believed that this study does provide some insight and understanding about the harassing and interesting problems posed by the goals of business firms in general, and more particularly the goal structure of some listed firms on the JSE.

Two outstanding observations are paramount: firstly, executives consider different goals to be of varying importance; and secondly, although not so obvious when seen in terms of answers to individual questions by themselves, the results of this survey clearly support the major hypothesis underlying this study - the validity of the wealth maximization objective - which appears to be applicable for the majority of firms which participated in this survey.

For more specific conclusions, the following may serve as a background: A normative science like business economics is built on a set of hypotheses aimed at explaining the behaviour and actions of the empirical object investigated, namely the business firm. In this sense, theory must be tested solely by its ability to predict and explain the likely actions of the empirical object. The hypotheses or normative theories must be continually verified against actual experience. However, it is possible to construct a number of theories, all producing hypotheses, which can be supported to a greater or lesser extent with empirical evidence. In such cases it is imperative to decide among the different competing theories, a choice according to Friedman, ${ }^{21, p p .3-43}$ governed by the relative simplicity and operational usefulness of such theories in the business environment. The simpler the normative theories, the fewer data are required for predictive purposes on how firms ought to act and the more usable are such theories because the predictions are more accurate and generally more applicable. Such theories are thus more desirable.

Based on the above requirements of normative theories and their accuracy and applicability, the following concluding remarks may be made:

- In a mixed economy like the South African, private firms are the main source of real wealth-creation. This wealth is created by maximizing the differences between inputs and outputs, which is then restated in the profit maximization concept. Profits provide taxes that make possible government expenditure on numerous projects, including also socially desirable projects.

By means of the profit-motive, the ultimate aim of business firms is to render services to society at large by the provision of goods and services and the provision of employment with fair wages and good working conditions. The firm is thus serving the community, but is also earning in this process earning a profit. The evidence from the past century is clear that the greater the freedom of firms to pursue their own 'selfish' profit-seeking goals, the greater the good they perform for society as a whole. Not only do they thereby create jobs for workers, and better and cheaper products and services, but they also yield returns for shareholders who have put their savings at risk. Therefore, the profit-motive must not be abnegated.

- Business firms, being part of the community, do have an undeniable responsibility towards its immediate society: clean air, unpolluted streams, housing and recreation for employees, donations to universities and the like. But there are limits to pursuing social ends with other people's (shareholders') money, however desirable these may be. Executives are not politicians - they have no mandate to perform functions of the central government, thus forming a government in exile. Shareholders should be consulted on the distribution of profits for social ends. A number of subsidiary social aims must, however, be considered, such as avoiding pollution of the environment, wasting of scarce resources and failing to take into account the interests of the consumer. A balance must be found between the primary profit and wealth creating objectives, and certain secondary 'obligations' that are also very important. It is management's prime task to reconcile these should any conflicts arise.

- In the process of ensuring the maximization of profits, returns on equity capital, shareholder wealth, turnover and other secondary goals, a number of constraints or limitations on freedom of action toward goal achievement must be met by management. Other parties who have an interest in the firm must not be harmed in the pursuit of wealth-creation activities. Because the maximization concept possesses certain absolute characteristics, preference must be given to the concept of 'satisfactory' profits, rate of return, etc., as opposed to the maximization concept. Satisfactory results are objectively definable as target returns, taking all possible constraints into account. 
- As an objective decision criterion for choosing among alternative courses of action, profit maximization per se does not provide an operationally feasible measure for ranking alternative courses of action in terms of their economic efficiency, except with very limited assumptions. The goal of profit maximization is too simplistic in that it disregards the risk and timing of returns. Maximization of shareholders' wealth expressed in terms of maximization of the market value of shareholders' wealth is appropriate because the effects of all financial decisions are in some way or another included in this parameter. Shareholders react to unsatisfactory investment and dividend decisions by penalizing the price of ordinary shares and react to satisfactory decisions by paying a premium for the share. Thus all financial decisions affect shareholder wealth. The major difference between the profit and rate of return maximization goals, and the goal of shareholder wealth maximization is that the latter goal deals with all the complexities of the business environment, while the profit and rate of return maximization goals do not. Thus, wealth maximization or the value of ordinary shares provides a performance index which takes into account a number of variables not included in the profit and rate of return maximization concepts; wealth maximization is a dynamic presentation of the static profit and rate of return maximization concepts.

- Since risk is always present in all activities of the firm, this phenomenon cannot be ignored. Capital is invested on behalf of the owners with the anticipated returns thereon uncertain, while other financial obligations are certain. The maximization of the shareholder value should be the sole financial objective in the long run because this value represents the shareholders' reward for supplying the venture capital. Theoretically then, maximization is proper because the return on risk-bearing capital is the residue after other fixed obligations have been met.

- Finally, it is important to realize that this empirical investigation of the goal structure of firms and the ensuing report represent an abstraction from the complexities of reality. In business economics, more particularly business finance, the goal of shareholder wealth maximization is no exception. Many executives indicated in their reponses that the goal of shareholder wealth maximization is a simplistic presentation of a series of highly complex activities.

The goal of shareholder wealth maximization is only broadly descriptive of what most firms attempt to do most of the time. It is not an absolute statement nor should it be interpreted as a literal statement of fact. Even more importantly, the goal of shareholder wealth maximization is primarily a normative goal - just as business economics is a normative science. Wealth maximization as a normative goal indicates what firms ought to do and nıeets the criteria of a normative theory.

Formulated in this way and more specifically weighing the opinions of the executives, it is clear that most firms do act in accordance with the wealth maximization goal, but at the same time also take into ac- count the interests of other parties. Expressed in terms of each of the possible individual parameters of the wealth maximization goal as formulated by Levy and Sarnat, ${ }^{6.526}$ that is in terms of either the maximization of the firm's total market value, or the price per share of ordinary shares, or the value of owners' equity, it is not surprizing to find that some firms do not appear to act in accordance with one or more of these parameters.

\section{References}

1. For a discussion of the goals of firms in general, see Reynders, H.J.J. 'Aspects of the goal of the firm in the world of today'. $S$ Afr. J. Econ., 434), Dec. 1975, pp.421-445.

2. For empirical research findings on social responsibility, see W'agenaar C.F. 'Social responsibility: The changing role of business in South Africa'. S. Afr. J. Bus. Mgml., 10(3), 1979. pp. $93-100$

3. Joy, O.M. Introduction to Financial Management. Illinois: R.D. Iruin, 1980.

4. Van Horne, J.C. Financial Management and Policy, 5th ed., New Jersey: Prentice-Hall, 1980

5. Cohan, A.B. Financial Decision Making. Englewood Cliffs, N.J.: Prentice-Hall, 1972.

6. Shareholder wealth maximization may be defined in terms of (a) the maximization of the firm's total market value; (b) the price per share of its ordinary shares; or (c) the value of its owners' equity. See Levy. H. \& Sarnat, M. 'A pedagogic note on alternative formulations of the goal of the firm'. J. Bus., 50(4) Oct. 1977, p.526.

7. Social responsibility: Improvement of quality of life of employees through means other than wage and salary adjusiments: creation of social infrastructure, such as encouraging the cultural and educational development of the community served by the firm; any type of social action(s) aimed at the community at large.

8. The names of executives and addresses of all listed firms were obtained from The Stock Exchange Handbook. Volumes 1 and II, 1979 and 1980. The research was done in mid.1980.

9. Edmonds, C.P. \& Hand, J.H. 'What are the real long-run objectives of business?'. Bus. Horizons, 19, December 1976.

10. See Poolman, J. 'Die opkoms yan die beroepsbestuurder en enkele implikasies daarvan', Professorale intreerede, Publikasiereeks van die $R A U, A 45$, Johannesburg, 1971

11. Berle. A.A. (Jr.) \& Means G.C. The Modern Corporation and Private Property, revised ed. Neu York: Harcourt, Brace \& World, Inc., 1968. (first ed. 1932.)

12. Reid, S.R. Mergers, Managers and Economy. New York: McGrau-Hill, 1968

13. Reid, S.R. 'Is merger the best way to grou?' Bus. Horizons, Indiana University Graduate School of Business. Vol. XII, Feb. 1969.

14. Werkema, H.G. 'Enige opmerkingen over het winststreven in de onpersoonlijke onderneming . Maandbl. Accountancy en Bedrijfshuishoudkunde, No. 2, Feb. 1964.

15. Solomon, E. The Theory of Financial Management. New York Columbia Lniversity Press, 1963

16. Baumol, W.J. Business Behaviour; Value and Growth. Neu York: Macmillan, 1959. Ch. $5 \& 6$

17. Rothschild, K.W'. 'Price theory and oligopoly'. In Stigler. G.J. \& Boulding, K.E. Readings in Price Theory. London: George Allen \& Unuin, 1953.

18. Gordon, R.A. 'Short period price determination in theory and practice. Am. Econ. Rev., Vol. XXXVIII, No. 3, June 1948.

19. Fellner, W'J. Comperition Among the Fen: Oligopoly and Similar Market Structures. New York: Alfred A. Knopf. 1949. Ch. 1, 4, $5 \& 6$.

20. March, J.G. \& Simon, H.A. Organizations. New York: John Wiley \& Sons, 1958.

21. Friedman, M. Essavs in Positive Economics. Chicago: Chicago University Press, 1953. 


\section{APPENDIX I Comments regarding statements on} social responsibilities and wealth maximization

Statement 19: Do you agree/disagree with the following statement: The firm and its managers are, after all, subject to the same moral codes which control all the other activities of society. The law requires certain things of us. But beyond this lies the ethical, which, in the real sense, fills the gap between the law and the actual decisions taken by management, its actual behaviour. And in this area management is guided by its own sense of right and wrong. Conceived of in this way, the firm, in meeting social obligations, allows a considerable measure of managerial discretion.

Nearly $91 \%$ of the executives endorsed statement 19 (see also Table 7). Those who agree argued as follows:

- Ethics, as decided by management, should be in black and white e.g. in policy statements and other directives.

- Loaded statement. Every profession has a high degree of discretion. Because we are concerned with emotional 'profit', you imply the 'ugly face of capitalism'.

Statement 20: The objectives of wealth maximization and social responsibility are basically contradictory.

Executives disagreeing:

- Social responsibility as a secondary goal is not contradictory to wealth maximization, but if taken to unnecessary extremes - YES!

- Our job is to use the factors of production as efficiently as possible. When our operation is successful the community as a whole benefits. This is social responsibility.

- It is a matter of degree. A little casting of bread on the water is good.

- If a large group totally ignores its social responsibility, its reputation, image and thus earnings, will eventually be affected.

- The sensible (rather than the permissive) application of social responsibilities should motivate personnel to improve production.

- If you take a long-term view, then profit maximization and a degree of social responsibility are hand in hand.

- In South Africa's context our social responsibility arises from the concern about political stability - an important parameter in the environment in which we try to achieve wealth maximization.

- In the long term socially responsible action must enhance business capability.

- The creation of wealth is for all to share and is in the interests of society.

Statement 21: Social responsibility is simply another prerequisite that management must consider in trying to satisfy the wealth maximization objective.

Responses of some executives who endorsed the statement:

- Not 'simply another' prerequisite, but a necessity to permit attainment of wealth maximization in the long term.

- Without social responsibility it is impossible to maximize the value of the company.

- We need to strive for a suitable political environment for the business to survive.

A typical responses in disagreement:

- Not necessarily, although the objective must be to achieve a maximum compatibility.

Statement 22: Social responsibility and wealth maximization are among many objectives that management pursues.

Responses of executives who agreed with the statement:

- They are in fact the two major objectives.

- The firm must be profitable primarily, as well as conduct itself in a socially responsible manner.

Arguments of those who disagreed:

- Profit is the main objective, but it must not be attained in a manner that is harmful to the community.

- Wealth maximization is the key objective - social responsibility is one of the many subsidiary objectives.

Disagree responses to statement 23: Owing to increased emphasis on moral and social responsibility, management now places less emphasis on stockholder wealth than it did, say, ten years ago.

- Believe management is now more conscious.

- Probably true in the USA, UK and Western Europe, but not in South Africa at this stage.
- Other companies talk more of social responsibility now, our company has always regarded social responsibility as important.

- Placing more emphasis on social responsibility does not imply less emphasis on shareholders' wealth.

\section{APPENDIX 2 Comments on the goal of shareholder wealth maximization}

- Historically this is certainly the case. The dynamic political environment in South Africa has, however, focused greater attention on the social responsibility aspect.

- Agree with the statement with the proviso that it be understood that to achieve this primary objective, considerable attention must be paid to employee job satisfaction, training, etc.

- I agree, but most executives know that keeping a happy staff and meeting social responsibilities, leads to long-term growth and maximization of shareholder wealth.

- Principle is correct, but 'maximization' is vague and cannot be defined. Objectives are set to maximize returns on assets over the long and short term, taking into account environmental risks, etc.

- Yes, agreed. Corporate objectives (1) To maximize the value of the shareholders' investment over the long run - both in respect of capital value and dividends - by achieving returns of ... (confidential detailed figures and percentages omitted).

- Correct, because you are not working with your own money but with that of your shareholders.

- I do not agree with the statement. I believe 'the long-run objective' is maximizing the profitability of the firm. Being concerned about market capitalization, a price per share can at times be in conflict with the long-run objectives as stated.

- Correct - because if you do not, you will be replaced.

- This statement is basically correct because in achieving long-term maximization of shareholder wealth, the company more readily achieves other primary and secondary objectives.

- Our main object is to run a successful business by keeping the members of the staff excited and on their toes; to take advantage of opportunities and use original marketing ideas to increase the business and profits. We never think of the shareholder wealth, but this naturally follows if we succeed in our work.

- Maximizing shareholders' wealth is not a prime objective. Maximizing profits and then using this to safeguard investment, a fair return and to meet social responsibilities, has been my objective. The continuation of employment for my 2000 employees is important to me. ( 35 years experience.)

- Agreed on the understanding that this is what will keep free enterprise healthy and capable of improving overall wealth. In the process, management must ensure that the company is contributing to social stability.

- I would put it differently: ' . . . seek several objectives, but maximizing profits for the benefit of shareholders, employees, customers, the country and society in general, is the primary long run ...'

- True, because this is the basic understanding between management and shareholders.

- Perhaps after the student has had the full range of experiences and traumas of running an organization he would be less inclined to make the statement.

- Only partly correct. It is the game of business they enjoy, applying intelligence, honesty, prudence and energy that results in shareholders' wealth.

- Insofar as 'shareholder wealth' relates to accumulated profits or distributed dividends, I agree. Market price of share is not an objective consideration.

- This ought to be the objective and is frequently the stated formal objective. In practice it is often not the primary objective.

- I would agree with the statement, but believe strongly that business per se has great social responsibilities as well as providing scope for development within a specific business of its own employees, which in turn contributes to the well-being of the country. 